\title{
University, věda, výchova a globální vývoj
}

\author{
Pavel Kovář \\ Envigogika 2007/II/3 - Recenzované články/ Reviewed Papers \\ Publikováno/Published 30. 12. 2007
}

DOI: http://dx.doi.org/10.14712/18023061.24

\begin{abstract}
Abstrakt:
Ekologické problémy se $v$ souvislosti $s$ globální klimatickou změnou, $s$ poklesem obyvatelnosti krajiny, s čerpáním zdrojů nebo se změnami životního stylu stávají výrazným politickým tématem. Zároveň $s$ tím, jak $v$ akademické sféře $i$ u politiků začíná vítězit funkce univerzit coby společenského resp. ekonomického agens, rostou nároky na vysokou úroveň výstupů činnosti těchto škol jako základu věrohodnosti rozhodování v rưzných oblastech.
\end{abstract}

Přestože humboldtovský model univerzit se posunul ve prospěch utilitárních základů vzdělanosti, i u nás sillí volání po diferenciaci vysokých škol podle náročných kritérií k financování (research universities, polytechnics). Nejen politické strany, ale možná ještě více občanská sdružení mající $v$ programu kvalifikovaně působit $v$ oblasti udržitelného rozvoje, budou potřebovat k osvětě "tvrdá data" a údaje verifikované standardními prostředky vědy. Proto budou potřebovat špičkové odborníky v biologické, krajinné či sociální ekologii a měly by aktivněji pracovat na jejich získávání (kvalita uvnitř̌), aby získaly na pozadí poklesu důvěryhodnosti politických stran větší respekt navenek (kvalita vně).

\section{Klíčová slova:}

$\mathrm{xxxx}$

\section{Abstract:}

Environmental problems - in the context of global climate change, reduction in the capacity of the landscape to support life, resource exhaustion or lifestyle changes - have become an important political theme. At the same time, the fundamental social and economical function of universities has start to prevail. On top of this, demands on the high quality of its "outcomes" as a basic level of reliability for decision making processes grow. Universities are thus being differentiated according to their research performance (as research universities/polytechnics) - a process is especially visible in the Czech context. All stakeholders including NGOs will more require yet more "hard data" and information verified by standard procedures of science, and the need for high-level experts in all fields will grow.

\section{Key words:}

$x x x x$ 
Jak se za posledních 15 let změnila ekologická politika a jaké jsou její perspektivy? Jsou dnes ještě platné myšlenky, které prosazoval na všech úrovních Josef Vavroušek?

Motto:

"Je zřejmé, že prostě musíme postupně budovat - co nejrychleji samozřejmě - systém péče o životní prostředí, který by byl součástí systému sebeřizení společnosti, tedy schopnosti usměrňovat sebe sama. A to předpokládá především zavést solidní ekologickou legislativu, především v oblasti daní, úvěrů atd. Za druhé to znamená vytvořit instituce, které by byly schopné rozvíjet tuto legislativu a zároveň ji prosazovat a kontrolovat dodržování... Za třetí je nutné dobudování informačního systému v celé oblasti a pomocí něho celkové propojení systému péče o životní prostředí, který by umožňoval prístupy od celku $k$ částem a od částí $k$ celku a kombinaci celostního $i$ detailního pohledu na postupy jak v širším, tak v místním měříku." (J.v. 1991, z rozhovoru v knize Klíčová slova - 1989, Oftis 2007).

V únoru 2003 vydala Evropská komise dokument podněcující debatu o univerzitním vzdělávání v propojené Evropě (EU). (Česká republika se stala členem EU 1. května 2004.) Definice pojmu univerzita sem klade všechna vzdělávací zařízení poskytující vysokoškolskou výuku, tedy i typu "polytechnics", "Grandes Ecoles" či "Fachhochschulen". Za vznikajícími vzdělávacími koncepty stojí především zvýšení konkurenceschopnosti evropských vysokých škol. Získávání mimořádných talentů, jejich udržení ve studiu a posléze na odpovídajících pozicích $v$ oborech, $v$ tvưrčí činnosti a $v$ ekonomicky významných aplikacích je předmětem stále narưstající soutěže $v$ mezikontinentálním globalizovaném prostoru. Pojem "znalostní Evropa" vznikl jako termín popisující žádoucí stav v EU na zasedání Evropské rady v Lisabonu (březen 2000). Od té doby Evropská unie buduje tzv. Evropský výzkumný prostor, dále evropský prostor celoživotního vzdělávání, má podrobný program cílů pro výchovně-vzdělávací systémy a programy práce pro sbližování systémů vysokoškolského (Boloňský proces) i odborného (Kodaňská deklarace) vzděláván.

Znalostní společnost a její ekonomika se opírá o kombinaci čtyř nezávislých složek: (1) vytváření poznatků v rámci vědeckého výzkumu, (2) jejich předávání ve vzdělávacím procesu, (3) jejich šiření prostřednictvím informačních a komunikačních technologií a (4) jejich využívání při technologických inovacích. Logicky z toho vyplývá, že i role vysokoškolské vzdělávací soustavy nabývá na významu v kontextu zaměstnanosti, kvalifikovanosti, globální občanské odpovědnosti, mocenské nezávislosti a zároveň sociální soudržnosti, úspěchu v ekonomické soutěži a vědomí hodnot v demokratickém zřízení.

V Evropě dnes existují asi 4 tisíce vysokých škol, v EU přibližně 3300. Rozdíly mezi nimi jsou značné - ve zpưsobu řízení, provozu a organizaci, v podmínkách získávání a zaměstnávání pracovníků a v kvalifikačních procedurách. Jejich principiální fungování je založeno na 200 let starém humboldtovském modelu se základem ve výzkumu a odvozené pedagogické činnosti. Současné výzvy jsou košaté a nutí přemýšlet o větší diferenciaci uvnitř vyššího vzdělání (rostoucí zájem o studium, reorganizace znalostí, tlak na spolupráci škol a výrobní sféry, internacionalizace, perspektivy celoživotního přizpưsobování a růst počtu míst produkujících znalosti). Spontánně vznikají instituce více specializované na jisté oblasti výzkumu i výuky nebo na snahy spojené se strategiemi regionálního rozvoje (integrace obyvatel formou vzdělávání dospělých, rekvalifikace apod.). Přitom odpovědnost za vysoké školy zưstává na členských státech - na národní nebo regionální úrovni. Proto jsme svědky trendu zvládat nastíněné požadavky přenesením odpovědnosti $v$ přiměřeném měřítku do mezinárodní dimenze. Srovnatelnost, průhlednost a vzájemné uznávání vzdělávacích systémů po Evropě je hlavní motivací pro zvýšení mobility studentů a učitelů resp. vědců, jinak společný trh práce zvýší úniky mozků a lokální ztráty vynikajících mladých i zkušených lidí. 
EU chce uskutečňovat podporu univerzitám jak ve výzkumu, tak vzdělávání. Po první linii znamená tato podpora přibližné pokrytí $1 / 3$ rozpočtu z rámcových programů (např. existující stipendia Madame Curie). Kromě tzv. 6. nebo ted' již 7. rámcového programu do značné míry na podporu vzniku mladých a interdisciplinárních týmů, můžeme zmínit také akční plán "Věda a společnost" zř́zený s cílem koordinovat na národní úrovni dialog s občany, vědeckou etiku, roli žen ve vědě a vědeckou výchovu (PhD studium). Podpora pro vysoké školy má dále plynout v oblasti technologických inovací ze Strukturálních fondů EU a od Evropské investiční banky. V linii druhé, vzdělávací, je už několik let známý a některými školami hojně využívaný program SOCRATES/ERASMUS, podmíněný Evropským systémem uznávání kreditů (ECTS), který postupně zavedla již většina našich univerzit nebo jejich fakult. Jiný program, LEONARDO, se zaměřuje na projekty mobility mezi školami a podnikatelským prostředím. Dále je tu možnost pro vysoké školy účastnit se iniciativy eEurope, jež podporuje on-line komunikaci mezi studenty i mezi výzkumníky. Navíc stále existuje program TEMPUS otevřený pro všechny země světa a kromě toho návrh programu Erasmus-World se zacílením přilákat ke studiu v Evropě vynikající studenty z ostatních zemí světa. Americká Fulbrightova komise by také neměla zůstat nezmíněna ve stínu ryze evropských aktivit, nebot' představuje nezanedbatelný prostředek celosemestrální výměny jak renomovaných, tak mladých pracovníků univerzit mezi námi a USA, tedy euroatlantického civilizačního prostoru.

První opravdová univerzita byla založena v Bologni v 11. století, následovaly Paříž a Oxford ve 12. století. Tyto dávné prríklady a tisíce imitací pokračují v růstu, podle místa také $v$ prosperitě. Ačkoli se změnily, rámec zưstává stejný. Na druhé straně je potřebné říci, že žádné instituce nepřetrvávají po 9 století bez adaptací. Bylo to zhruba před sto lety, když kardinál John Henry Newman, tvưrce katolické univerzity v Dublinu, vyslovil definici funkce ideální univerzity, která se později stala slavnou. Ale ačkoli bývá často citována, jeho inspirující vize nese jen skrovnou podobnost s univerzitami dneška. Newman, stejně jako Cicero, věří v potřebu pronásledování pravdy oddělenou od "nezbytných starostí" lidstva. Jeho univerzita by se proto měla věnovat získávání poznání pro ně samé, měla by být "vysoce ochrannou silou všeho poznání a vědy, faktů a principů, objevů a zkoumání, pokusů a spekulací."

K tomu má dnešní realita daleko: univerzity dneška často oslavují své výdobytky ve smyslu produkce užitného poznání. Nadto - rostoucí měrou jako diseminátoři takového typu znalostí - opravňují tímto zpưsobem svůj nárok na veřejný zájem. Mnohé moderní univerzity byly postaveny výslovně na těchto utilitárních základech. Např. unie amerických univerzitních ústavů (colleges) se snaží zlepšovat provozování zemědělství a mechanických dovedností. Dokonce i staroslavná učení zaznamenávají obrat k tomuto myšlení - britský Oxford se po určitém váhání rozhodl přijmout dotaci od saudského milionáře k etablování obchodní školy. Cambridge - jeho rival - akceptovala s hrdostí, když Bill Gates si toto místo vybral pro svou extramurální počítačovou laboratoř Microsoftu.

V pozadí transformace účelu a image univerzit leží mocné síly - jedna intelektuální, druhá politická. Kořenem té první je triumf přírodních věd v průběhu 20. století, který sesadil z piedestalu ideál univerzálního kultivování mysli. Kdo by chtěl dělat fyziku bez trénování invence vedoucí k silikonovému čipu? Druhá velká síla vedoucí k proměně univerzit byl růst demokracie a poptávka po masovém vzdělání. Většina univerzit byla po svou dlouhou historii výsadou pro nevelké elity. Během celého 17 . století - jak píše Christopher Lucas, profesor arkansaské univerzity ve Fayettsville - navštěvovalo Harvard méně než 600 žáků. Ale v rozmezí 130 let mezi roky 1840 až 1970, kdy americká populace vzrostla $12 \mathrm{krát}$, počet zapsaných na univerzitu narostl $417 \mathrm{krát}$. Do poloviny 90 . let dosáhly USA téměř 4000 akreditovaných vysokých škol. Dosažení vyšších stupňů vzdělání - určité terciární kvalifikace - se stává nepostradatelným průkazem k slušnému zaměstnání. Nezbytně dochází k expanzi počtu univerzit vytvářených stovkami a tisíci akademických pracovních míst a k požadavku na veřejné finance vkládané do vysokoškolského systému. Současně s tím se objevuje názor, že tento fenomén je fatální pro kvalitu. Když v 60. 
letech probíhala v Británii debata, zda zvětšit její elitní systém univerzitního vzdělávání, Sir Kingsley Amis - autor "Št́astného Jima" - vynesl soud: „Víc znamená hưr̆”...

V naší době začíná vítězit podoba univerzit coby společenského resp. ekonomického agens - nikoli jako obraz tvưrce vzdělanosti, trénování svěžího myšlení a proměňovatele kultury. V takové "ekonomii založené na poznání", kde myšlenky a manipulace s nimi znamenají víc než tradiční faktory produkce, musí univerzity vypadat stále víc jako majetková hodnota. Technokratická fráze ze studie OECD zní hodně odlišně od výše zmíněné Newmanovy rétoriky - systém vzdělávání v ní nachází místo coby součást „"národního inovačního systému", tedy spíš než morální a kulturní síla je zapojen jako inkubátor nových průmyslových a technologiemi ovládaných ekonomik.

V takovém klimatu „všichni" tedy musí mít titul - to je patrně největší jednorázová změna v historii univerzitního vzdělávání, označovaná v hrozném žargonu administrátorů vysokého školství jako „masifikace”. Bill Clinton pravil, že aspoň dva roky vzdělávání po 2. stupni školy by se mělo pro Američany stát stejně běžné jako je dokončená střední škola. A ačkoli $v$ nejbohatších zemích klesá počet mladých, tento demografický vývoj nic nemění na tom, že počty studentů budou pokračovat $v$ nárůstu, protože existuje stimulovaná poptávka po terciárním vzdělání.

Politici vědí dobře, že ne všichni studenti jsou schopni přijímat prospěch z tradičních kursů nabízených tradiční univerzitou - to jest v modernizovaném pojetí takovou, která integruje výuku a výzkum (myšlenka pochází od Wilhelma von Humboldta z berlínské univerzity na počátku 19. století). V zásadě má Humboldtův ideál k doporučení mnohé a stejně jako Newman je často připomínán v diskusích o správném smyslu vysokého učení. Avšak v praxi se po příchodu "masifikace" prosazují různé typy "polytechnik", které zajisté mají velký význam např. v rozvoji regionů.

Výzkumné univerzity nemohou být masové, protože se mj. stávají drahými na to, aby přijímaly všechny mladé lidi hladovějící po nadstandardním vzdělání. Samozřejmou odpovědí by proto mělo být vytvoření systému, $v$ němž se některé instituce specializují na výzkum a výuku, jiné na učení podle praktické poptávky. Takový systém je jak levnější, tak adaptabilnější vůči různorodým potřebám a talentům studentů. Touto cestou se již vydalo několik zemských vlád v Německu, také Finsko, Švýcarsko a Rakousko se pokouší tímto způsobem školy diferencovat.

Zrychlující se informační propojování světa, jehož jsme svědky, nás nemůže nepřesvědčit, že znalosti a inovace jsou vládnoucím faktorem našeho individuálního i institucionálního bytí, a že se staly klíčovou otázkou celé naší současnosti. Snaha pochopit, jak znalosti vznikají, jaké je jejich využití a přenos, už dala vzniknout rozsáhlé literatuře nejrůznějších oborù $v$ mnoha zemích. $V$ úspěšné společnosti je převažující díl obyvatel označován jako znalostní pracovníci, kteří jsou schopni využívat globalizující se potenciál informací a poznatků k tvưrčímu transferu.

Ta složka univerzitního poslání, která po staletí uchovávala tradice, brání dnes přizpůsobovat se rychleji změnám - dovolujeme, aby ve společensko-správní sféře nabývaly na důležitosti rưzné expertní komise, poradenské firmy a ziskově orientované výcvikové agentury, které tradičním vysokým školám odebírají nemalou část vzdělávacích fondů (ve většině národních společností jsou to vládní a podnikatelský sektor, které zaujímají vưdčí pozici ve věcech znalostí a inovací, zatímco veřejné vysoké školy se často straní i jen elementární diskuse o tom, co všechno tento přechod znamená - vždyt budoucnost ještě nenastala, a tradice nezávislosti resp. neangažovanosti má svou hodnotu). Na stůl rozhodovacím orgánům přicházejí legislativní návrhy, v nichž oprávnění 
rozdávat certifikáty na kvalifikovanost může poměrně snadno získat třeba i efemérní a konjunkturalistické, ale formálně nenapadnutelné spolčení.

Druhým problémem je, že všude ve světě je k dispozici tolik informací, že lidé potřebují navíc ještě další intelektuální dovednosti, jako např. kritické a srovnávací myšlení, k tomu, aby dokázali rozlišit, které znalosti jsou relevantní a užitečné, kterých je lépe se zbavit, a které je třeba podržet v kognitivním vědomí jako v bance $k$ eventuálnímu pozdějšímu uplatnění. Jinými slovy, problém exploze informací není ani tak $v$ možnostech přístupu k nim jako ve snaze intelektuálně přetížených lidí zredukovat informace na zvládnutelné mezní množství tím, že většinu jich vyloučí.

Třetí problém spočívá v tom, že většina lidí ani neví, že nějaká „informační propast" existuje, a pokud to vědí, pak jim bud' chybí motivace, aby s tím něco udělali, anebo je to intelektuálně paralyzuje. Vysoké školy jako tradiční centra vytváření a šíření znalostí stojí před dvojnásobnou dávkou nezbytných změn: především budou postupně muset své učební plány, způsob financování, režim a řízení přizpưsobit novým podmínkám a, za druhé, vyvinout metody, jak příštím generacím předávat nové znalosti a dovednosti, z nichž některé dosud ani nejsou na světě. Zvláštní pozornost bude třeba věnovat vzdělávací soustavě určené k tomu, aby se dokázala přeorientovat na výuku znalostí a dovedností potřebných ke vzdělávání - v globálním kontextu - po celý život.

Úspěšní lidé budou muset mít v budoucnosti spektrum způsobilostí, ale i flexibilní dovednosti orientované na schopnost vytvářet vztahy dưvěry s příslušníky mnoha jiných kultur. Podle kulturologů však problém spočívá $v$ tom, že $v$ dobách společenských a politických změn jsou to právě mezilidské vztahy, které utrpí jako první. A tak důvěra, na kterou se nyní pohlíží jako na „kapitál”, je podstatně důležitá - a zároveň nedostatková.

Pokud jde o časovou perspektivu, jednou z kulturních proměnných veličin je "orientace na budoucnost", která se pro rozvoj znalostní a inovační společnosti považuje za zvláště důležitou. Mnoho kultur, zejména těch, které v nedávné minulosti existovaly pod diktátorskými režimy, stále ještě žije $v$ minulosti anebo přinejlepším $v$ současnosti, a to v jakési formě mentality přeživších. Proto, abychom nabyté dovednosti neuplatňovali na nízké funkční úrovni, potřebujeme navíc poznávací dovednosti k tomu potřebné. Kromě samotných znalostí o změně tedy musíme také rozvíjet své znalosti o znalostech: měli bychom usilovat o metaznalosti - o nalezení a předávání způsobů, jak se efektivně učit, jaké údaje a jak sbírat a jak je vyhodnocovat nebo aplikovat.

\section{Výchozí teze pro přípravu Bílé knihy terciárního vzdělávání}

„Evropským univerzitám se nedaři vytvářet intelektuální a tvưrčí energii, která je zapotřebí ke zvýšení zatím slabé ekonomické výkonnosti kontinentu. (...) Přiliš málo z nich jsou mezinárodními centry výzkumné excelence přitahujícími nejlepší talenty z celého světa. (...) K tomu, aby evropské univerzity uspěly ve svém úsilí získat více prostředkü, musí nejprve prokázat, že umí efektivně nakládat s prostředky, které mají nyní. Proto mnoho členských států EU zahájilo reformu zastaralých systémů řízení univerzit. (...) V EU je téměř 2.000 univerzit, z nichž vysoký podíl poskytuje postgraduální vzdělání, naproti tomu v USA je okolo 3.300 institucí terciárního vzdělávání, z nichž pouze 215 poskytuje postgraduální vzdělání a pouze 100 z nich jsou uznávané výzkumné univerzity. (...) Přiliš mnoho evropských univerzit směřuje ke stejným cílưm, v jejichž dosažení ani nemohou doufat, protože dostupné zdroje se rozdělují přiliš plošně."

Závěry "Tematického hodnocení terciárního vzdělávání", které bylo uveřejněno v listopadu 2006 (hodnocení OECD): 
Dnešní prioritou je zajistit, aby Česká republika měla systém vysokého školství, který bude schopen efektivně fungovat ve stále konkurenčnější oblasti vysokého školství $v$ Evropě $i$ ve světě a který bude prispívat $k$ rozvoji země v kontextu znalostní společnosti. (...) Všechna doporučení, která tato zpráva dává - at' se týkají struktury systému, řizení institucí, zdrojů, rovnosti, výzkumu a inovací, pracovního trhu, zajištování kvality nebo internacionalizace - kladou silný důraz na potřebu změnit "zahledění sama do sebe", které bylo nezbytné pro vybudování systému, na zaměření se ven. Toto vnější zaměření má mnoho dimenzí - znamená silnější vzdělávací vazby na zaměstnavatele, regiony a na trh práce, vývoj výzkumných a inovačních partnerství s podniky, prümyslem a jinými vysokými školami, větší roli externích aktérů v řízení systému a institucí a $v$ akreditaci, větší soukromé príspěvky na náklady na vysoké školství a rovněž otevřenost směrem $k$ Evropě $i$ světu. (...) V silně diverzifikovaném systému každá jednotlivá instituce naplňuje odlišným způsobem tři zásadní poslání - výuku, výzkum a vývoj (VaV) a tzv. třetí roli (community service).

Akutnost tvorby strategie reformy terciárního vzdělávání (tj. Bílé knihy) a následných realizačních kroků (včetně legislativního rámce) je dána také jedinečnou přiležitostí, kterou skýtá využití prostředků strukturálních fondů Evropské unie v období 2007-13. Především operační programy Vzdělávání pro konkurenceschopnost (OP VK), Výzkum a vývoj pro inovace (OP VaVpI) a částečně Podnikání a inovace (OP PI) obsahují finanční nástroje jak k systémové podpoře reformy, tak k podpoře individuálních projektů. Bylo by osudnou chybou nabízenou príležitost nevyužít.

Cíl týmu je prostřednictvím tvorby Bílé knihy dojít k reformě českého vysokého školství. Stručný přehled hlavních tezí pokrývajících problematiku ve třech poměrně široce definovaných oblastech, ve kterých se přirozeně propojují základní strategické komponenty reformy:

- $\quad$ expanze systému a proměna jeho struktury à cesta k vyšší vzdělanosti, rovnějším šancím a sociální mobilitě (vazba na střední školství);

- r rízení a financování vysokých škol à přirozená cesta k poptávkovému modelu, diverzifikaci (rozvrstvení systému), konkurenci a tudíž k vyšší kvalitě;

- $\quad$ výzkum a vývoj, integrace univerzit do "vnějšího systému" à cesta k excelenci a k soukromým zdrojưm na výzkum a vývoj.

Každá z oblastí je popsána ze čtyř hledisek:

- $\quad$ největší problémy a hrozby, nebudou-li problémy koncepčně řešeny;

- $\quad$ stav, kterého chceme dosáhnout (realisticky);

- nástroje (mechanismy), které je třeba v systému uplatnit, aby se k tomuto stavu začal přibližovat;

- $\quad$ širší podmínky, které budou muset být splněny pro úspěšnou realizaci změn. 


\section{Cílový stav}

Za cílový stav je možné považovat takový systém, který bude schopen bez výraznějších zásahů $z$ vnějšku relativně rychle a pružně reagovat na potřeby trhu práce (profesně orientované terciární vzdělání), špičkového výzkumu a vývoje (vysoce kompetitivní univerzitní vzdělání spojené se špičkovým výzkumem) a společnosti (poptávka po vysokoškolském vzdělání jako komoditě zajištujúcí životní úspěch a vzestupnou sociální mobilitu).

\section{Nástroje a mechanismy}

K popsanému cílovému stavu Ize dospět řadou kroků, které musí tvořit vnitřně provázanou reformní strategii:

- Integrace některých VOŠ do terciárního systému formou jejich transformace (akreditace) na neuniverzitní VŠ, případně jejich spojení s již existujícími VŠ. Je třeba počítat s tím, že ty VOS, které nebudou splňovat požadavky nebo se k transformaci na neuniverzitní VŠ nerozhodnou, se budou moci stát centry dalšího post-sekundárního (nikoli terciárního) vzdělávání s významným postavením v daném regionu a v procesu celoživotního vzdělávání;

- Dokončit restrukturalizaci vysokoškolského studia a to tak, že bakalářské programy budou vesměs relativně uzavřenými celky, u nichž návaznost na magisterské programy bude pouze jedním z ukazatelů. $\mathrm{V}$ případě bakalářských programů by měl být kladen větší dưraz na jejich profesní orientaci a úzkou vazbu na potřeby trhu práce;

- Změnit pravidla akreditace jednotlivých typů programů tak, aby byly v odpovídající míře zohledněny vstupy, procesy i výstupy (inputs, throughputs, outputs) včetně vyššího podílu externích členů (zástupců uživatelů, partnerů a veřejnosti);

- Zavést registr učitelů VŠ, kteří by mohli garantovat obor pouze na své mateřské univerzitě, $v$ této souvislosti zvážit změnu habilitací a profesorských rízení (jednou z variant je vázat profesury na konkrétní akademické pozice);

- Vytvořit transparentní mechanismy zajištúující přirozenou diferenciaci VŠ s ohledem na jejich cíle, kapacity a výsledky práce (vysoká škola musí mít možnost ekonomicky uspět ve kterékoli ze zvolených kategorií);

- Zavést pravidelné hodnocení jednotlivých VŠ s možným využitím pro financování a zpřehlednění nabídky studia pro potenciální zájemce; vytvořit finanční nástroje odstraňující překážky formování aspirací na dosažení vŠ vzdělání zejména u dětí pocházejících ze znevýhodňujících sociálních poměrů (účinnější systém sociálních stipendií, půjčky na pokrytí životních nákladů během studia, spoření na vzdělání, smluvní zvýhodnění příležitostné práce studentů atd.). Veškeré pưjčky musí být spláceny kontingenčně (tj. splátky podle velikosti př́ijmů).

\section{Širší podmínky dosažení cílů}

Princip excelence je třeba prosadit $v$ jeho mnoha vrstvách - kromě mezinárodní excelence ve výzkumu vymezit i excelenci v transferu poznatků a spolupráci s praxí a excelenci v souvislosti $s$ potřebami trhu práce ("príprava absolventů na míru"), rozsáhlými programy dalšího vzdělávání a uplatněním distančního vzdělávání. Tomu je nutné uzpůsobit i akreditační procesy, požadované standardy a obvyklé „kariérní dráhy". 
Je důležité koncentrovat kapacity výzkumu a vývoje, zejména s ohledem na úspory $v$ investicích do prístrojového vybavení a vytváření dostatečně dimenzovaných týmů (včetně vhodné formy sítí a partnerství). Koncentraci je nutno chápat nejen místně, ale i na úrovni řízení týmů a projektů. Zároveň je nutné zohlednit regionální potřeby výzkumu a vývoje v souladu se širšími strategickými záměry regionů a potřebami aplikační sféry.

Pozitivní změny Ize dosáhnout pouze s hladinou financování umožňující skutečný rozvoj: u institucionální podpory mělo jít nejméně o cca $10 \mathrm{mld}$. Kč ročně a pro účelovou podporu (poskytovanou pouze Grantovou agenturou ČR a Technologickou agenturou ČR) o cca 15 mld. Kč ročně.

Je celosvětově prokázané, že zvýšené výnosy univerzit z komerčních spoluprací jsou nutné a ozdravující, nicméně nikdy nenahrazují zdroje pro standardní vzdělávací činnost a orientovaný (aplikovatelný) základní výzkum.

Konec citace ministerského materiálu - a ted’ zpátky k souvislostem mezi problémy aktuálního systému vzdělávání a hlavním tématem naší konference. Otázku, zda je koncept (trvale) udržitelného rozvoje vizí nebo ideologií, cítím jako př́liš jdoucí vstříc právě (utopickým) vizionářům anebo (obsedantním) ideologizátorům pohybujících se $v$ politice. Pro mne je koncept poprvé definovaný v Naší společné budoucnosti G.H. Brundtlandové (1987) především rámcovým pojmenováním adaptivního procesu doprovázeného demokratickým systémem společenského chování, který klade důraz na již známé nebo potenciálně objevované samoobnovné mechanismy civilizačního provozu. To, že zahrnuje hodnotové normy obecně podporující život, ruku v ruce s kognitivní sférou resp. s poznáním reality, považuji za samozřejmé. Právě tyto všechny atributy obsahuje více konkrétní definice uplatněná Josefem Vavrouškem (aniž by odporovala obecné a z toho titulu někdy kritizované - definici Světové komise pro životní prostředí a rozvoj při OSN):

"Trvale udržitelný rozvoj společnosti je takový rozvoj, který současným i budoucím generacím zachovává možnost uspokojovat jejich základní životní potřeby a přitom nesnižuje rozmanitost př́rody a zachovává přirozené funkce ekosystémů. "

V době, kdy dnes již etablované subdisciplíny ekologie jako „restoration ecology" (ekologie obnovy) nebo teorie ostrovní biogeografie dávající do vztahu biodiverzitu $s$ dalšimi atributy zemského povrhu coby jedno z teoretických jader krajinné ekologie (landscape ecology) byly v plenkách (Van Andel J. et Aronson J. 2006, Farina 1998), Vavrouškovo předjímání klíčových pojmů a jejich spojení budí respekt. Po půldruhé dekádě oborového vývoje u nás je otázkou, nakolik zdůrazňovat mezioborovou výlučnost nauky o životním prostředí a podpírat tím institucionální vydělování (stále vznikají takto pojmenované institucionální jednotky, na školách dokonce fakulty apod.) interdisciplinární povaha, zejména dík mnohotvárným aplikacím technik a metodik, je v souvislosti s bouřlivým technologickým rozvojem, komputerizací atd. dnes už běžným fenoménem u velké části (i př́rodních) věd (např. geochemie, geoinformatika, etologie, makroekologie, vývojová biologie, paleovědy, biomedicína atd.).

Od času zakladatelských počinů Josefa Vavrouška se tuzemská politická a veřejná scéna vyvíjela klikatě a s doprovodem stále hlubšího matení, rozmělňování a inflace slov: krátkodechost nereálných plánů podsunutých pod slůvko vize a ideologizace sloužící k odstřelu i rozumných konkrétních aktů přinesly ovoce v zkresleném posuzování problémů životního prostředí. "Sustainability" pak mủže část veřejnosti vnímat jako něco pejorativního, brzdícího, negativistického, pokud věří slovům politika, že "ekologie" není vědecké odvětví, že „ekolog" je extremistický živel náchylný k terorismu s předponou ekoapod. Mimořádnou nebezpečnost na pozadí diskusí o globálních ekologických změnách představuje ideologický atak ekonomistů proti "environmentalismu" ve stylu "zloděj 
volá: chyt'te zloděje", snažících se volný trh myšlenek obehnat ohradou jedné nadřazené, univerzální, všeobjímající a paradoxně jako monolit prezentované a tudíž opět ideologizované oborové sféry ekonomie. Proč je tedy vzdělanost a $v$ tomto kontextu vnímavost k světovým standardům kvality vysokoškolské výchovy tak důležitá pro kvalifikované fungování společnosti typu STUŽe i pro občanskou veřejnost jako celek? Vezmeme-li coby ideologický koncentrát (ne snad nejdokonalejší, ale dík cílené propagandě asi nejznámější) knihu Modrá, nikoli zelená planeta. Co je ohroženo: klima, nebo svoboda? (nakl. Dokořán, 2007), člověk s dostatečným středoškolským všeobecným, neřku-li jakýmkoli vysokoškolským vzděláním by měl mít natolik kvalifikovanou rozlišovací schopnost $v$ rámcové orientaci po dějinách, ekonomii lidských statků, ekonomii přírody (ekologii) a obecně přírodovědných a společenských oblastech, aby zpozorněl po zjištění, že:

- podtitul je tím hlavním sdělením směřujícím k diskreditaci myšlenkového okruhu, v jehož jádru je poselství o integritě ekonomie př́rody a společnosti; argumentace proti pravděpodobnostním dopadům lidské činnosti na výchylky globálních parametrů přírody je při bližším zkoumání eklektická i chybná a podle všeho jen zástupná $v$ účelovosti přirovnávání $k$ totalitním ideologiím nacismu nebo komunismu, které jsou při srovnání s environmentalismem současné doby dokonce bagatelizovány,

- $\quad$ rozporu s předkládanými generalizacemi je na české politické scéně typický př́klon zeleného hnutí k pravému středu, pramenící mj. i z významné účasti tohoto hnutí na politické změně v r. 1989 (listopadovým událostem předcházely environmentálně motivované nepokoje proti komunistickému režimu v industriální oblasti severních a a západních Čech, dlouhodobě "polodisidentsky" působila Ekologická sekce Čs. biologické společnosti při ČSAV známá jako zdroj vypracování a úniku dokumentu o stavu životního prostředí Československa na Západ s následnými represemi režimu, apod.),

- politizace původně odborné debaty tu jde tak daleko, že neodpovědný signál vyslaný široce propagovaným nařčením z totalitarismu je bezprostředně po ventilování myšlenek vnímán českými "republikány" jako reálná pobídka k neonacistické demonstraci proti "totalitě zelených" (záŕi 2007), tedy proti demokratické složce popřevratového spektra v politice,

- dopad na zájmy ČR v zahraniční politice je i ze zorného pole akademické sféry předvídatelný; je-li vědecký pracovník členem např. Mezinárodní asociace pro nauku o vegetaci (IAVS) nebo Mezinárodní asociace pro ekologii krajiny (IALE), je dobře obeznámen $s$ faktem, že $v$ těchto světových oborových komunitách členěných na tematické větve nebo výzkumné pracovní skupiny již dlouhou dobu působí uskupení ostrovních států, jichž se globální změny (Flannery 2007) citelně dotýkají nejrůznějšími způsoby (extinkce bioty v okolí atolů a následná likvidace rybolovu, podléhání ostrovních potravních zdrojů nebo turisticky atraktivní prírody invazím vetřeleckých druhů organismů, atd.) - odtud snadno odhadnutelná váha podílu na neúspěchu např. při hlasování v OSN o členství ČR v Radě bezpečnosti,

- jiným symptomem politizace, tentokrát nikoli nechtěné, je ignorování standardní metodologie verifikace a zveřejňování vědeckých poznatků, projevující se mj. ve zneuznávajícím odsudku tzv. IPCC - Mezinárodního panelu pro klimatické změny zřízeném UNEP a WMO při OSN - po jím vydané několikadílné zprávě sestavené klimatology a dalšími odborníky na základě excerpce několika tisíc vědeckých článků v renomovaných časopisech vydaných v mezidobí od r. 2001 do současnosti,

- v úzké souvislosti $s$ předchozím je viditelná širší snaha potlačit tento zatím nejprověřenější model získávání poznání zahrnující všechny fáze vědecké metodologie a "odřiznout" ho jako věrohodný decizní podklad k dalším rozhodnutím ve správní sféře; průmět tohoto přístupu možno vidět bud' 
v navrhování "antikomise" pro hodnocení klimatických změn anebo i v rezervovaném postoji k univerzitní vzdělanosti (parafrázovaný komentář „máme přiliš mnoho profesorư" při formálním udělování zmíněného titulu by od autora seděl, kdyby šlo o srovnávání vlastního titulu neopřeného o vědecké publikace a tudíž žádné citační ohlasy v relevantní literatuře ve srovnání např. s jiným profesorem téhož oboru shodou okolností nyní kandidujícím na identickou státní funkci),

- hlásání jednolitosti ekonomie, resp. „alespoň té části, která si zaslouží být nazývána vědou" ve smyslu používání stejných pouček, stejných nástrojů analýzy atd.) potvrzuje chápání vědy jako něčeho, co principiálně nestaví na metodologických inovacích, co se nevětví, čemu neprísluší "nečekanost" v nalézání; empirická povaha ekonomie možná srovnatelné s medicínou uprostřed "věd o životě" navíc podporuje indikaci způsobu myšlení blízkého politikovi, nikoli badateli (protipríklad z díla reditele Gund Institutu of Ecological Economics, University of Vermont, USA: Constanza R., 1991: Ecological Economics: The Science and Management of Sustainability, nebo Tietenberg T., 2006: Environmental Economics and Policy),

- posun myšlenkového klimatu v koincidenci s množícími se fakty o změně klimatu globálního je korunován souzněním s prezentací kontroverzního filmu "Velký podvod s globálním oteplováním" M. Durkina (režisér pochází z okruhu bývalého měsíčníku Living Marxism, který vydávala britská Revoluční komunistická strana); pokleslost na úroveň směsného využívání pravd, polopravd, nápadné selektivity dat a vyložených zkreslení se stává dokonce zaužívanou metodou (brožura Globální oteplování: fakta místo mýtů, vyd. CEP, 2007).

Vážnost jen několika uvedených skutečností snad postačuje a nemá už nejspíš smysl přidávat další a další body nebo poukazy na vztahy mezi institucemi spřaženými s antienvironmentalistickou kampaní u nás a za mořem (americký neokonzervativní Heardland Institute, bruselský Center for the New Europe, Cato Institute...) a zájmovými financovateli velkorysého rozměru (světová firma Exxon Mobil). Potřeba špičkově vzdělané vrstvy pro věrohodné argumentační zázemí a jako silné záruky pro liberalizované prostředí trhu myšlenek bez ideologizujících omezení v rozvoji technologických (včetně ekotechnologických) trendů a možností, pro adaptivní zpětné vazby z nastíněných hrozeb vysvítá. Nejde jen o schopnost vzdělané generace naplnit preferované akademické atributy v podobě originálních výsledků vědy $v$ periodikách s nejvyšším citačním ohlasem, ale také o patenty a transfery do ohnisek výrobních nebo managementových aplikací. $\vee$ souvislosti s tím posledním jmenovaným by se nemělo zapomínat na koncepční výstupy směřované v intencích mezinárodních konvencí (např. Evropská úmluva o krajině, Council of Europe 2000) do správy území kontinentálního rozměru jako je metodologie sledování (monitoringu) změn a standardizace jejich hodnocení (např. Bunce a kol. 2005, 2008) - jedině tak Ize přispět k serióznímu získání dat $v$ relevantních prostorových a časových měřítcích, které mohou bud' vyvrátit, nebo potvrdit nynější tvrzení diskutérů na téma ekologických změn tam, kde ještě zbývají větší procentní pochybnosti.

"Jsem zodpovědný za program Občanského hnutí a považuji to v současné situaci za nejschůdnější zpưsob, jak se politicky aktivizovat. $V$ souvislosti s životním prostředím jsem presvědčený o tom, že lidé, kteř́ k tomu mají skutečně nějaký vztah, mají spolupracovat bez ohledu na stranickou prís/ušnost. Avšak myslím si, že to ukazuje daleko víc, že prostě do určité míry nás čeká stejně jako celou Evropu krize takových těch typických, hierarchicky budovaných politických stran. Že prostě lidi na to přestávají být zvědaví a že je třeba hledat nějakou jinou formu. Forma hnutí má dost nevýhod, především menší akceschopnost, pomalejší reagování na změny, ale jeho ctností je, že umožňuje korigovat velké chyby."

$$
\text { (J.V. 1991, z rozhovoru v knize Klíčová slova - 1989, Oftis 2007). }
$$




\section{Literatura}

- Bunce R.G.H., Groom G.B., Jongman R.H.G. et Padoa-Schioppa E. (eds.), (Associate Editors, , \& Bogers M., Brandt J., Hofer G., Garcia del Barrio J., Elena-Rossello R., Ispikoudis I., de Blust G., Gonzales-Avila S., Kovář P., Metzger M., Palo A., Roche P., Skånes H., Mücher C., Perez-Soba M., Pasta S., Wrbka T., Paelinx D., Ramos I., Peterseil J.), (2005). Handbook of Surveillance and Monitoring of European Habitats. Wageningen: Alterra.

- Bunce, R. G. H., Metzger, M. J., Jongman, R. G. H., Brandt, J., de_Blust, G., Elena-Rossello, R., ... Skånes, H. (2008). et Wrbka T., 2008: A standardized procedure for surveillance and monitoring European habitats and provision of spatial data. Landscape Ecology, 23(1), 11-25. Retrieved from http://link.springer.com/10.1007/s10980-007-9173-8 http://dx.doi.org/10.1007/s10980-007-9173-8

- Constanza, R. (1991). Ecological Economics: The Science and Management of Sustainability. New York: Columbia Univ. Press.

- Evropská úmluva o krajině a důvodová zpráva (2000). Strasbourg: Council of Europe.

- Farina, A. (1998). Principles and methods in landscape ecology. London ; Chapman \& Hall, c1998: London ; Chapman \& Hall, c1998. Retrieved from http://link.springer.com/10.1007/978-94-015-8984-0 http://dx.doi.org/10.1007/978-94$\underline{015-8984-0}$

- Flannery, T. (2007). Měníme podnebí. Minulost a budoucnost klimatických zmèn. Dokořán, Praha.

- Globální oteplování: Fakta místo mýtů . Praha: CEP.

- Klaus, V. (2007). Modrá, nikoli zelená planeta. Co je ohroženo: Klima, nebo svoboda. Dokořán, Praha.

- Tietenberg, T. (2006). Environmental Economics and Policy, 5th edition, Pearson/Addison. Boston: Wesley.

- $\quad$ Our common future (1987). New York: UN Brundtlands Commission.

- Van_Andel, J., \& Aronson, J. (2006). Restoration ecology. Carlton: Blackwell Publishing.

- Výchozí teze pro prípravu Bílé knihy terciárního vzdělávání, 19. 6. 2007 . . Retrieved from http://www.msmt.cz/vzdelavani/vychozi-teze-pro-pripravu-bile-knihy-terciarniho-vzdelavani

Adresa autora: Prof. RNDr. Pavel Kovář, CSc., děkan Př́rodovědecké fakulty
Univerzity Karlovy v Praze, Albertov 6, 12843 Praha 2, e-mail:
kovar@natur.cuni.cz


Časopis Envigogika vydává Centrum pro otázky životního prostředí UK. Vývoj časopisu je podpořen projektem OP VK Mezioborová sít udržitelného rozvoje.

Více najdete na internetových stránkách projektu mosur.czp.cuni.cz
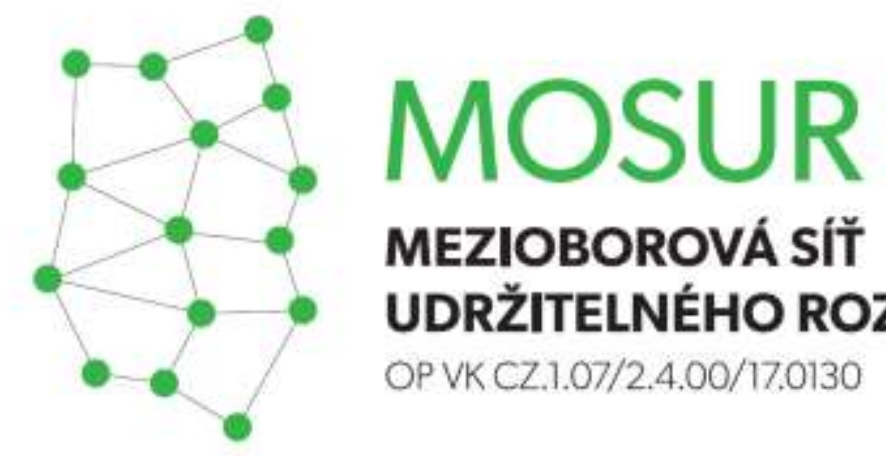

\section{MEZIOBOROVÁ SÍT} UDRŽITELNÉHO ROZVOJE

OP VK CZ.1.07/2.4.00/17.0130
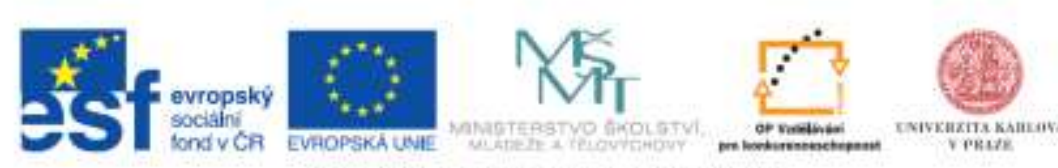

INVESTICE DO ROZVOUE VZDELAVANI 